\title{
Evaluation of Anxiolytic Activity of Ixora coccinea Linn. Ethanolic Extract in Swiss Albino Mice
}

\section{Shan P Mohammed*, Nasiya Latheef and Sri Ganeshan P}

Regional Institute of Medical Sciences and Research, Mahatma Gandhi University, Puthupally, Kottayam-686009, India

\begin{abstract}
Ixora coccinea Linn. (Family: Rubiaceae), a small to medium sized hardy shrub is cultivated for ornamental purpose and also it finds place in traditional Indian medicine. The objective of this study was to evaluate the anxiolytic activity of Ixora coccinea ethanolic extract. The methods used for this study are elevated plus maze paradigm test and Hole board test. The ethanolic extract ICEE shows a significant $(P<0.01)$ anxiolytic effect during the elevated plus maze test and the hole board test in a dose dependent manner when compared with the standard dose of diazepam.
\end{abstract}

Keywords: Ixora coccinea; Hole board test; Rota rod test; Diazepam

\section{Introduction}

In recent years, anxiolytic drugs have been among the frontrunners in terms of the number of prescription written in medical practice. This may be due to the tense life-style imposed on man by the current competitive atmosphere. Patients facing a life-threatening illness commonly experience anxiety over their fears and uncertainties about their future. Currently available drugs used for treatment of psychological disorders are not totally devoid of side effects. At present, the etiological factors responsible for these disorders are not expected to decrease; there is a need for new drugs with less adverse reactions. In the search for new therapeutic products for the treatment of neurological disorders, medicinal plant research, worldwide, has progressed constantly, demonstrating the pharmacological effectiveness of different plant species in a variety of animal models [1].

Ixora coccinea Linn (Family: Rubiaceae), a small to medium sized hardy shrub is cultivated for ornamental purpose and also it finds place in traditional Indian medicine. Roots contain aromatic acrid oil, tannin, fatty acids. Leaves yield flavonols, kaemferol, quercetin, proanthrocyanidines, phenolic acids, and ferulic acids. Flowers yield cyanidins, flaconboides, and cooling material related to quercitin [2]. The plant is reported for diverse pharmacological properties including anti-inflammatory and antimitotic activities [3]. Leaves and flower extracts were reported to possess antimicrobial activities [4]. Flower extract of showed protective effect against cyclophosphamide and cisplastin induced systemic toxicity [5]. The roots of the plant I. Coccinea are mostly used as an astringent, antiseptic, stomachic, sedative etc. Traditionally roots are also used in diarrhoea, dysentery, gonorrhea, in loss of appetite, hiccups, fever, sores and chronic ulcers. The leaf and stem often used as an ablution for infantile, sedative [6]. The present study deals with evaluation of the anti anxiety and myo relaxant properties of ethanolic extract of the Ixora coccinea whole plant.

\section{Materials and Methods}

\section{Plant material}

Fresh plants of Ixora coccinea Linn. was collected from local areas of Chengannur, Kerala in March, 2013. This plant was authenticated by Dr. Jomy Augustine, Head of the Department, Post Graduate and Research Dept. of Botany, St. Thomas College, Pala, Kottayam. The reference sample of the plant has been kept in college museum for future reference. After due authentication fresh matured whole plant was collected, cleaned thoroughly with fresh water and dried under shade.

\section{Preparation of ethanolic extract}

The shade dried whole plants were pulverized in a mechanical grinder to obtain coarse powder. These were subjected to extraction by Soxhlet method using ethanol as solvent. Evaporation of solvent from the extracts was done by rotary vacuum evaporator. A sticky mass were obtained after evaporation of solvent. The samples were stored at $10^{\circ} \mathrm{C}$ till further use. At the time of administration, a suspension was prepared by using the extracts in $1 \% \mathrm{w} / \mathrm{v}$ of sodium Carboxy Methyl Cellulose (sodium CMC).

\section{Animals used}

Swiss albino mice of either sex 20-30 gm of body weight obtain from Animal House, Department of Pharmacology, RIMSR, Puthupally, Kottayam. Animals were kept in standard animal house condition. Prior to use, the mice were housed in polypropylene cages in group of six animals under natural light-dark cycle. They were provided with commercial food pallets and tap water ad libitum. Cleaning and sanitation work was done on alternate days. Paddy husk was provided as bedding material. All the observations were made at room temperature in a noiseless diffusely illuminated room. The cages were maintained clean and all experiments were conducted between 8 am to $3 \mathrm{pm}$.

\section{Acute oral toxicity studies}

This was performed to ascertain safe dose of the extract by the acute oral toxic class method by the Organization of Economic Cooperation and Development (OECD) 423 guidelines. Female Albino mice selected by random sampling technique were used for the study. The animals were selected and grouped, three animals per group. They were kept fasting four hours prior to the treatment and the test substance was administered in a single dose by the oral route. A single administration of starting dose of $2000 \mathrm{mg} / \mathrm{kg}$ body weight p.o of the extract (ethanolic extracts were suspended in $1 \%$ CMC solution) was administered to three female mice. After the substance had been administered, the food

*Corresponding author: Shan P Mohammed, Regional Institute of Medical Sciences and Research, Mahatma Gandhi University, Puthupally, Kottayam-686009, India, Tel: 0385-2414539; E-mail: shanpm1234@yahoo.com

Received January 01, 2014; Accepted January 15, 2014; Published January 22 2014

Citation: Mohammed SP, Latheef N, Sri Ganeshan P (2014) Evaluation of Anxiolytic Activity of Ixora coccinea Linn. Ethanolic Extract in Swiss Albino Mice. Clin Exp Pharmacol 4: 146. doi:10.4172/2161-1459.1000146

Copyright: $(2014$ Mohammed SP, et al. This is an open-access article distributed under the terms of the Creative Commons Attribution License, which permits unrestricted use, distribution, and reproduction in any medium, provided the original author and source are credited. 
could be withheld for a further one-to-two hours. They were noted individually after dosing, at least once during the first 30 minutes, periodically during the first 24 hours, with special attention given during the first four hours and thereafter for a total of 14 days. Body weight of the mice before and after treatment will be noted. Any change in skin colour, fur, eyes, somatomotor activity and behavioral pattern will be observed and also signs of tremors, convulsions, diarrhea, lethargy and sleep were noted.

The quantitative phytochemical analysis of Ixora coccinea ethanolic extract was carried out in order to ascertain the presence of some active phytoconstituents like alkaloids, carbohydrates, glycosides, saponins, tannins, proteins, amino acids, flavonoids and reducing sugars.

\section{Evaluation of anxiolytic activity of Ixora coccinea extract}

Elevated plus maze test: Swiss albino mice (20-25 gm) were taken and divided into four groups, each group comprised of 6 animals. The two doses of extract ( 200 and $400 \mathrm{mg} / \mathrm{kg}$ ) were administered orally 60 min before test and the standard group was treated with diazepam (2 $\mathrm{mg} / \mathrm{kg}$ ) intraperitoneally $30 \mathrm{~min}$ before test. The control group was treated with $1 \% \mathrm{w} / \mathrm{v}$ sodium CMC orally, $60 \mathrm{~min}$ before test. To begin a test session, mice were placed on the open arm facing the center of the maze. An entry into an arm was defined as the animal placing all four paws over the line marking that area. The number of entries and the time spent in the open and closed arms were recorded during a 5-min test period. Every precaution was taken to ensure that no external stimuli, other than the height of the plus-maze could invoke maze anxiety [7].

Hole board test: Swiss albino mice (20-25 gm) were taken and divided into four groups, each group comprised of 6 animals. The two doses of test extract ( 200 and $400 \mathrm{mg} / \mathrm{kg}$ ) were administered orally 60 min before test and standard group was treated with diazepam ( $2 \mathrm{mg} /$ $\mathrm{kg}$ ) intraperitoneally $30 \mathrm{~min}$ before test. The control group was treated

\begin{tabular}{|c|c|c|}
\hline Treatment Group & $\begin{array}{c}\text { Time spent in open arm } \\
\text { during } \mathbf{5} \text { minutes test } \\
\text { period }(\mathbf{s e c})\end{array}$ & $\begin{array}{c}\text { Total number of entries into } \\
\text { arms during 5 minutes test } \\
\text { period }\end{array}$ \\
\hline $\begin{array}{c}\text { Control } \\
(1 \% \text { CMC, p.o) }\end{array}$ & $23.4 \pm 4.410$ & $10.84 \pm 0.4014$ \\
\hline $\begin{array}{c}\text { Standard drug } \\
\text { (Diazepam } 2 \mathrm{mg} / \\
\text { kg, i.p) }\end{array}$ & $222.5 \pm 11.815^{\star *}$ & $4.84 \pm 0.4773^{* *}$ \\
\hline $\begin{array}{c}\text { ICEE } \\
(200 \mathrm{mg} / \mathrm{kg}, \mathrm{p} . \mathrm{o})\end{array}$ & $80.84 \pm 4.729$ & $9.167 \pm 0.4013$ \\
\hline $\begin{array}{c}\text { ICEE } \\
(400 \mathrm{mg} / \mathrm{kg}, \mathrm{p} . \mathrm{o})\end{array}$ & $140.84 \pm 16.902^{\star *}$ & $8 \pm 0.5774^{* *}$ \\
\hline
\end{tabular}

All values are Mean \pm SEM and statistically analyzed using One-Way Analysis of Variance (ANOVA) followed by Dunnett's multiple comparison test, $n=6$.

${ }^{* *} \mathrm{P}<0.01$ When compared with control.

Table 1: Effect of ICEE and Diazepam on Elevated Plus Maze test.

\begin{tabular}{|c|c|}
\hline Treatment Group & $\begin{array}{c}\text { Number of nose poking during a 5 } \\
\text { minutes test period }\end{array}$ \\
\hline Control (1\% CMC, p.o) & $43.34 \pm 2.629$ \\
\hline $\begin{array}{c}\text { Standard drug } \\
\text { (Diazepam } 2 \text { mg/kg, i.p) }\end{array}$ & $3.67 \pm 0.3333^{* *}$ \\
\hline $\begin{array}{c}\text { ICEE } \\
(200 \mathrm{mg} / \mathrm{kg}, \text { p.o })\end{array}$ & $21.67 \pm 1.202^{*}$ \\
\hline ICEE \\
$(400 \mathrm{mg} / \mathrm{kg}$, p.o)
\end{tabular}

All values are Mean \pm SEM and statistically analyzed using One-Way Analysis of Variance (ANOVA) followed by Dunnett's multiple comparison test, $n=6$.

${ }^{* *} \mathrm{P}<0.01$.

${ }^{*} \mathrm{P}<0.05$ When compared with control

Table 2: Effect of ICEE and Diazepam in Hole Board experiment. with $1 \% \mathrm{w} / \mathrm{v}$ sodium CMC orally, 60 min before test. At the start of the test, mouse is placed in the edge of the board. The number and duration of head poking into the holes during a 5 minutes period is taken as the measurement [8].

\section{Results}

The ethanolic extract of Ixora coccinea was found to be non-toxic up to the dose of $2000 \mathrm{mg} / \mathrm{kg}$ and did not cause any death, therefore it is considered as safe. Hence $1 / 10^{\text {th }}$ and $1 / 5^{\text {th }}$ of this dose i.e., $200 \mathrm{mg} / \mathrm{kg}$ and $400 \mathrm{mg} / \mathrm{kg}$ body weight was used for the activity.

The quantitative phytochemical analysis of Ixora coccinea ethanolic extract indicates the presence of some active phytoconstituents like alkaloids, carbohydrates, glycosides, saponins, tannins, flavonoids and reducing sugars.

In elevated plus maze apparatus, the total duration in open arm and total number of arm entries during 5 minute period are statistically compared. When compared with control, the time of standard group in open arm was significantly increased $(\mathrm{P}<0.01)$. ICEE 200 is not significant and ICEE 400 is significant $(\mathrm{P}<0.01)$ when compared with control. The standard drug (diazepam $2 \mathrm{mg} / \mathrm{kg}$, i.p) showed a significant increase in time spent in open arm and a significant decrease in number of arm entries. The standard group $(\mathrm{P}<0.01)$ and ICEE $400(\mathrm{P}<0.01)$ group showed significant reduction in total number of arm entries, when compared with control (Table 1).

In hole board test, the number of nose poking after treatment is statistically compared. When compared with the control group, Standard drug (diazepam $2 \mathrm{mg} / \mathrm{kg}$, i.p) and ICEE 200 and $400 \mathrm{mg} / \mathrm{kg}$, p.o, both significantly decrease the number of nose poking (Table 2).

\section{Discussion}

Anxiolytic activity was evaluated by using elevated plus maze paradigm and hole board test. The Elevated Plus-Maze (EPM) test represents one of the most widely used animal models for screening anxiolytics [7]. The fear due to height induces anxiety in mice when placed on the apparatus. Mice will normally prefer to spend much of their allotted time in the closed arms. This preference appears to reflect an aversion towards open arms that is generated by the fears of the open spaces. In the present study, the total time in open arm was found to increase by the test extract $(400 \mathrm{mg} / \mathrm{kg} \mathrm{p.o})$. This indicates the anxiolytic activity of ethanolic extract of Ixora coccinea Linn. ICEE 400 $\mathrm{mg} / \mathrm{kg}$ shows significant reduction in total arm entries which indicates the depression of locomotion by higher dose of Ixora coccinea Linn.

The Hole Board model was another apparatus used in the measurement of head dipping behavioral responses of rodents to an unfamiliar environment. Decrease in the number of head dips was measured and groups that received ICEE $(200 \mathrm{mg} / \mathrm{kg}, 400 \mathrm{mg} / \mathrm{kg})$ and diazepam $2 \mathrm{mg} / \mathrm{kg}$ had shown significant decrease in head dip counts. The anxiolytic effect of alkaloids [9], flavonoids [10] and saponins [11] has been previously reported and, therefore, we suggest that these anxiolytic effects may be due to the above constitutes. Most of the anxiolytic agents exert their action by opening of activated GABAchloride channel. It is also reported that many flavonoids were found to be ligands for the GABA-A receptors in the central nervous system. The above results reveals that the ethanolic extract of Ixora coccinea have satisfactory anxiolytic effect.

\section{Acknowledgement}

We take this privilege and pleasure to acknowledge the contributions of all teaching staffs of University College of Pharmacy, who have been inspirational and supportive throughout our research work. 
Citation: Mohammed SP, Latheef N, Sri Ganeshan P (2014) Evaluation of Anxiolytic Activity of Ixora coccinea Linn. Ethanolic Extract in Swiss Albino Mice. Clin Exp Pharmacol 4: 146. doi:10.4172/2161-1459.1000146

\section{References}

1. Zhang ZJ (2004) Therapeutic effects of herbal extracts and constituents in animal models of psychiatric disorders. Life Sci 75: 1659-1699.

2. Vadivu R, Jayashree N, Ksthuri C, Rubhini K, Rukmankathan G (2010) Pharmacognostical standardization of leaves of Ixora coccinea linn. J Pharm Sci Res 2: 164-170.

3. Yang LW, Wu DH, Tang X, Peng W, Wang XR, et al. (2005) Fingerprint quality control of Tianjihuang by high-performance liquid chromatography-photodiode array detection. J Chromatogr A 1070: 35-42.

4. Seethadevi B, Nair CRS, Paniker PV (1991) Antimicrobial activity of leaves of Ixora coccinea. Indian Journal of Pharmaceutical Sciences 53: 92.

5. Latha PG, Panikkar KR (1999) Modulatory effects of ixora coccinea flower on cyclophosphamide-induced toxicity in mice. Phytother Res 13: 517-520.

6. Yadava RN, Jain S (2005) A new bioactive flavone glycoside from the seeds of Melilotus indica All. J Asian Nat Prod Res 7: 595-599.
7. Lister RG (1987) The use of a plus-maze to measure anxiety in the mouse. Psychopharmacology (Berl) 92: 180-185.

8. Boissier JR., Simon P (1964) Dissociation de deuxcomposantesdanslecomporte mnetd'investigation de la souris. Archives InternationalesdePharmacodynamieet de The'rapie 147: 372-387.

9. Martínez-Vázquez M, Estrada-Reyes R, Araujo Escalona AG, Ledesma Velázquez I, Martínez-Mota L, et al. (2012) Antidepressant-like effects of an alkaloid extract of the aerial parts of Annona cherimolia in mice. $J$ Ethnopharmacol 139: 164-170.

10. Li H, Zhou P, Yang Q, Shen Y, Deng J, et al. (2011) Comparative studies on anxiolytic activities and flavonoid compositions of Passiflora edulis 'edulis' and Passiflora edulis 'flavicarpa'. J Ethnopharmacol 133: 1085-1090.

11. Wei XY, Yang JY, Wang JH, Wu CF (2007) Anxiolytic effect of saponins from Panax quinquefolium in mice. $J$ Ethnopharmacol 111: 613-618. 